\title{
ALEKSANDER WÓJTOWICZ
}

Czarne i czerwone. Masy ludzkie w poezji polskiego futuryzmu

Artykuł opisuje, w jaki sposób polityczne zaangażowanie polskiego futuryzmu wpłynęło na poetyckie reprezentacje tłumu. Futuryści przedstawiali masy jako rezerwuar energii na tyle silnej, że zdolnej nie tylko do obalenia dotychczasowego porządku, lecz również do stworzenia zrębów przyszłego ładu. A jednocześnie poszukiwali adekwatnych sposobów ich przedstawienia w popularnych słownikach epoki, sięgając po elementy dyskursu konserwatywnego, komunistycznego oraz militarnego. Spoiwem tych heterogenicznych, nie zawsze zbieżnych wyobrażeń była apoteoza rewolty, pojmowanej jako wyzwanie rzucone nowoczesnemu porządkowi (i kapitalizmowi).

Słowa kluczowe: futuryzm, awangarda, dwudziestolecie międzywojenne, rewolucja, barykada, Bruno Jasieński, Anatol Stern 
Literatura polska powitała nadejście „ery tłumów” z niepokojem. $\mathrm{Na}$ początku dwudziestego stulecia pobrzmiewały w niej argumenty bliskie tym, jakie wysunął Gustaw le Bon w Psychologii ttumów (1896). Spekulował tam, że wstąpienie na arenę dziejów tytułowego żywiołu „będzie jedną z ostatnich faz cywilizacji Zachodu, zapowiedzią powrotu do pierwotnej anarchii, która poprzedza każde kiełkowanie nowych form społecznych" (Le Bon 1994, 14). Dystans naukowca szedł przy tym w parze z rozterkami konserwatysty; pierwszy opisywał to zjawisko przez analogię do procesów rozkładowych, drugi - wyrażał nadzieję, że ówczesna cywilizacja mimo wszystko uniknie takiego losu, a jednocześnie rzucał pod adresem mas ciężkie oskarżenia. Kumulowały się one w formule „duszy tłumu”, którą Le Bon przedstawiał przy użyciu retoryki publicystycznej, sięgając między innymi po reifikację („w tłumie jednostka staje się automatem”) oraz dehumanizację („zstępuje o kilka stopni niżej w swym rozwoju kulturowym”). Była to karykatura „duszy” samoświadomej i racjonalnej wspólnoty: „Tłum to nagromadzenie miernoty, nie (...) inteligencji”, stwierdzał aforystycznie, a jednocześnie roztaczał wizję, w której rozwój cywilizacji był dziełem „drobnych grup arystokracji intelektualnej”, zaś upadek - dziełem powodowanych szałem mas (Le Bon 1994, 23). „Dusza tłumu” od początku towarzyszyła dziejom ludzkości, a w momentach kryzysu występowała na pierwszy plan i wyładowywała się w aktach zniszczenia, które obracały w proch dorobek wielu pokoleń.

Jej złowieszczy cień unosił się także nad literaturą polskiego modernizmu (Pułka 1993). O ludzkich masach pisano wówczas z pogardą, strachem i podziwem, przy czym w retorycznym słowniku epoki najmocniej zaznaczył się pierwszy z wymienionych afektów. Zadomowił się zwłaszcza w słowniku młodopolskich poetów, którzy w ślad za Stanisławem Przybyszewskim (1899) kreślili wyraźną linię podziału między wrażliwym artystą a motłochem, zaś ślady tego arystokratyzmu ducha błąkały się jeszcze w tekstach Witkacego, opatrzone mniej lub wyraźniej widocznym cudzysłowem ironii. Takie dystynkcje przesłaniały jednak problem o wiele bardziej złożony, jaki wybrzmiewał w tekstach pisarzy, którzy zwrócili uwagę na to, że u progu stulecia zaczęło wzrastać znaczenie mas. Na przykład Stanisław Brzozowski oraz Stanisław Liciński wyszydzali modną wówczas ludomanię, a jednocześnie podkreślali rosnące znaczenie proletariatu, próbującego wywikłać się spod presji władzy i wytwarzanych przez nią dyskursów (Walicki 2011, 152-211). Z tego względu opisywali masy z mieszanką podziwu i niepokoju; pierwszy wywoływała drzemiąca w nich potęga, drugi natomiast rodził podejrzenie, że owa siła może się wyładować w niekontrolowanych aktach 
destrukcji. W ambiwalencji takiej pobrzmiewały zarówno rozterki odziedziczone po wieku pary i elektryczności, jak i dylematy na wskroś aktualne, bo związane z wydarzeniami rewolucyjnymi i wojennymi, za których sprawą „dusza tłumu” zaczęła budzić żywe zainteresowanie pisarzy, przyglądających się jej z uwagą równą tej, jaką poświęciło jej wielu ówczesnych myślicieli (Sorel 2014; Tarde 1904).

Ważnym progiem w tym względzie był rok 1918. Niepodległość znacząco przeformułowała ramy literackich dyskursów tłumu, w snutych przez pisarzy projektach życia zbiorowego coraz częściej do głosu dochodził postulat upodmiotowienia mas. Z dzisiejszej perspektywy interesujące wydają się zwłaszcza utwory, które można uznać za świadectwo erozji konserwatywnych wyobrażeń pod naporem dyskursów, jakie podsuwały artystom inne sposoby estetycznej reprezentacji tłumu. W ówczesnych tekstach programowych, literackich i publicystyce zawrotną karierę robiło hasło „demokratyzacji”, które szybko podchwycili poeci nawołujący do przekształcenia tradycyjnej wspólnoty w nowoczesne społeczeństwo. Skamandryci wzywali do porzucenia romantycznego dziedzictwa i skupienia uwagi na szarym obywatelu, którego wynosili do rangi pierwszoplanowej figury nowych czasów (Julian Tuwim). „Lewica literacka” za znak nadejścia tych czasów uznała natomiast postępującą emancypację proletariatu (Aleksander Wat, Anatol Stern, Stanisław Brucz). Z tego powodu głosiła potrzebę silnego sprzęgnięcia nowatorskiej literatury z działalnością społeczno-polityczną, lecz akurat w tym przypadku przymierze wypaliło się na łamach kilku numerów Nowej Kultury (Loth 1965). Z kolei konstruktywiści opiewali uliczne tłumy, o których Tadeusz Peiper pisał w programowym tekście Miasto, masa, maszyna jako o „najcudowniejszym organizmie, piękniejszym niż wszystko, co stworzyła natura; złożonym i precyzyjnym w swym funkcjonowaniu jak maszyna”. Środkowa część tytułowej triady była w tym przypadku utożsamiana z „masą-społeczeństwem”, czyli „zbiorowością uorganizowaną” (Peiper 1972, 38-39).

\section{„Masa straszna i wspaniała”}

Inaczej „masę” pojmowali futuryści. W awangardowych słownikach wyraz ten zyskiwał zniuansowane znaczenia, ponieważ skupiał w sobie kluczowe cechy nowatorskich dyskursów estetycznych. Dla konstruktywistów była zalążkiem nowego ładu, natomiast dla futurystów liczyła się przede wszystkim jej energia kinetyczna, wyładowująca się w tyleż intensywnych, co nieprzewidzianych wybuchach. Opisywana przez nich
Niepodległość w znaczący sposób przeformułowała ramy literackich dyskursów tłumu, w snutych przez pisarzy projektach życia zbiorowego coraz częściej do głosu dochodził postulat upodmiotowienia mas. Z dzisiejszej perspektywy interesujące wydają się zwłaszcza utwory, które można uznać za świadectwo erozji konserwatywnych wyobrażeń pod naporem dyskursów, jakie podsuwały artystom inne sposoby estetycznej reprezentacji tłumu. 
„masa” ciążyła pod względem znaczeniowym w stronę „motłochu”, który - co znamienne - wiek wcześniej Samuel Bogumił Linde określił jako „wielki gwałt czasu podłego”, a więc jako stan skupienia przyjmowany przez zbiorowość w chwilach zachwiania obowiązującego ładu ${ }^{1}$. Konserwatyści upatrywali w nim zagrożenie dla cywilizacji („dusza tłumu” Le Bona), a futuryści - szansę na zdestabilizowanie i obalenie zmurszałego porządku.

Dlatego też w ich wierszach często dochodziła do głosu apoteoza mas ludzkich. Towarzyszyła jej prowokacyjna negacja instytucji sztuki, jak na przykład w wierszu rozpoczynającym się od słów: „zmęczył mńe język, jak twardy zlepek/ jestem jak człowiek, co lampy pszerosł./ $\mathrm{Na}$ skszyżowańu dwuh wrogih epok/ stoję, cyńiczńe gryząc papieros” (Jasieński 2008, 214-217). Taka deklaracja stała się punktem wyjścia do demonstracyjnego przekreślania wartości poezji, zarówno tej tradycyjnej, jak i najnowszej. Ambicje Jasieńskiego nie ograniczały się bynajmniej do rozważań metapoetyckich, bo wiersz został w wyraźny sposób przełamany na dwie części, pierwsza z nich dotyczyła poezji i została zakończona zarzutem, że była „utrzymanką eleganckich panów”, druga natomiast zawierała pochwałę „ekstatycznego tłumu zżartego pszes syfilis". Jakkolwiek szturmowanie granic sztuki było pozorne, bo Jasieński odwoływał się przede wszystkim do mocno osadzonej w tradycji literackiej estetyki brzydoty, to mimo wszystko w obrębie tekstu wyraźnie widoczne było przetasowanie dotychczasowych hierarchii. Rezultatem było przede wszystkim rozprzęgnięcie dotychczasowych więzów łączących zbiorowość; Jasieński opiewał nie osadzoną w strukturach nowoczesnego państwa grupę obywateli, lecz bezkształtną masę, która przelewała się przez ulice miast, to właśnie do niej skierowane zostało wezwanie: „Hodźće! Hodźce tu wszyscy! Pąsowi! We krwi!/ O Tłumie! O Motłohu! Tytańe! Narodźe!”.

Warto zwrócić uwagę na znamienny szczegół. Apostrofa została zapisana za pomocą ortografii fonetycznej, stworzonej jako protest przeciwko tradycyjnej formie zapisu, którą futuryści odrzucali jako zdezaktualizowaną i nieprzystającą do nowoczesnych form komunikacji. Dlaczego

1 Zob. Linde 1809, 146. Warto dodać, że progu minionego stulecia Stownik jezyka polskiego (1902) jako wyrazy bliskoznaczne do "motłochu” podawał „gawiedź, tałatajstwo, chmara, hałastra, zgraja, zbieranina" (Niedźwiedzki, Kryński i Karłowicz 1902, 1050). Mniej pejoratywne skojarzenia pojawiały się w traktowanych bliskoznacznie wyrazach „masa” i „tłum”; pierwsza określana była jako „wielka ilość, kupa, gromada, tłum” (Niedźwiedzki, Kryński i Karłowicz 1902, 892), natomiast drugi - „wielka gromada, kupa, ciżba, hurma, bezwładna masa, chmara, nawał ludzi” (Stownik jezzkka polskiego 1919, 68). 
zatem słowa „Motłoh” i „Tłum” zapisane zostały wielką literą? Dwie sprzęgnięte ze sobą odpowiedzi wydają się tutaj szczególnie interesujące: być może decyzja o takim sposobie zapisu wynikła z chęci wyrażenia szacunku dla adresata, co byłoby prawdopodobne o tyle, że cały wiersz to pochwała bezimiennego tłumu. W tym przypadku jednak dokonywałoby się to za pomocą zasad tradycyjnej pisowni, co jeszcze bardziej komplikowało i tak zawiły przecież projekt pisowni fonetycznej. Gest taki wpisywał się w ramy procesu upodmiotowienia mas, które w minionym stuleciu na fali dyskursów emancypacyjnych uzyskiwały nową tożsamość. Ale Jasieńskiego zdawała się interesować nie ostateczna konsekwencja tej przemiany, lecz raczej moment, kiedy na arenę dziejów wkraczała „olbżymia czarna masa, straszna i wspańała”.

Skąd owa „czarna masa” brała się w wierszach futurystycznych? Wytwarzały ją negatywne afekty, a zwłaszcza gniew i głód, jak w poemacie Jasieńskiego Pieśń o głodzie (1922), w którym mowa o „ludziach zagłodzonych w saharach milionowych miast” (Jasieński 2008, 71). Przedstawiony tam obraz wielkiej metropolii znajdował się na antypodach cywilizacyjnego optymizmu, widziane z perspektywy podmiotu miasto przybierało kształt samopożerającego się organizmu, gdzie zwłoki zmarłych były „rozdłubywane do kości” i przetwarzane na nawóz. Mroczna, wyraźnie ciążąca ku estetyce ekspresjonizmu wizja została dopełniona przez niespokojną, targaną elementarnymi impulsami masę.

Ale ludzka „czerń” nie była jedyną formą zbiorowości w poemacie. Jasieński wprowadził także inne stany jej skupienia, po ulicach miasta w sposób „rytmiczny i twardy” maszerowały oddziały wojska: „pszehodźły kompańe ruwno, jak na mustsze/ bez komendy tszymały swuj cudowny krok/ wszyscy porwańi jednym/ milionowym/ spazmem” (Jasieński 2008, 84). W podobnym rytmie, choć z zupełnie innych względów, szli zorganizowani w bojówki robotnicy, którzy wzywali do buntu przeciwko kapitalistom, zapowiadając nieuchronną i zwycięską rewolucję: „kto nam, kto nam teraz drogę zagrodzi samym?/ wszystko zmiażdżymy butami piękńi, ogromńi i ludzcy” (Jasieński 2008, 88).

Eksplozywny gniew, militarny porządek oraz „proletariacki samum” te cechy kształtowały różne wcielenia masy w Pieśni o głodzie. Różniło je praktycznie wszystko, łączył zaś fakt, że były zaprzeczeniem cywilnego społeczeństwa. Ten moment destabilizacji stanowił symptomatyczną cechę wielu tekstów futurystycznych, które powstawały nie tylko „na skrzyżowaniu dwóch wrogich epok” (Jasieński), ale również w czasie, kiedy tradycyjne reprezentacje mas ustępowały pod naporem nowych wyobrażeń. $\mathrm{Na}$ ich kształt wpłynęły niewątpliwie obrazy filmowe, bo przełom drugiej i trzeciej dekady minionego stulecia, to okres, gdy masy

Eksplozywny gniew, militarny porządek oraz „proletariacki samum” - te cechy kształtowały różne wcielenia masy w Pieśni o głodzie. Różniło je praktycznie wszystko, zaś łączył fakt, że były zaprzeczeniem cywilnego społeczeństwa. 
ludzkie stały się widzialne, kinematograf odkrył ich piękno, a jednocześnie wplótł w zideologizowane narracje (jak na przykład w filmach D. W. Griffitha, S. Eisensteina). Dominował w nich motyw wzburzonych tłumów, przewijający się w ówczesnych reprezentacjach wojny i rewolucji (Sajewska 2016), w których dionizyjski szał (Eksteins 1996) przeplatał się z przerażeniem, a tonacja apokaliptyczna - z ideą nowego początku.

Jankowski przedstawił zdestabilizowany świat industrialnego kapitalizmu. Poszczególne elementy przestały wypeł-

niać powierzone im zadania; ikona nowoczesnej efektywności, czyli fabryka, nie wytwarzała produktów, ponieważ ogłoszono w niej strajk, zaś karni dotychczas pracownicy zaczęli używać maszyn niezgodnie z przeznaczeniem.

\section{„Niebieskie oczy proletariatu”}

Metaforyka „świtu” patronowała też narodzinom polskiego futuryzmu. W październiku 1919 roku Jerzy Jankowski (w oryginalnej pisowni: Yeży Yankowski), uznawany za pierwszego z rodzimych reprezentantów tego nurtu, opublikował zbiór Tram wpopszek ulicy, który otwierał wiersz pod takim samym tytułem. Stanowił on jeden z pierwszych symptomów przełomu awangardowego w Polsce, a jednocześnie ujawniał ścisły związek pomiędzy radykalizmem artystycznym i społecznym, bo centralne miejsce w tekście zajmowała forma zbiorowości - proletariat.

Jankowski przedstawił zdestabilizowany świat industrialnego kapitalizmu. Poszczególne elementy przestały wypełniać powierzone im zadania; ikona nowoczesnej efektywności, czyli fabryka, nie wytwarzała produktów, ponieważ ogłoszono w niej strajk, a karni dotychczas pracownicy zaczęli używać maszyn niezgodnie z przeznaczeniem. Tokarz wytwarzał lufy, giser - granaty, drukarz zamiast gazet zajmował się przygotowywaniem i rozpowszechnianiem odezw, nieco mniej wyeksponowana rola w tym na wskroś patriarchalnym obrazie została przypisana robotnicom, które wypatrywały za bramą potencjalnego zagrożenia. Dopełnieniem przesyconego etosem rewolucyjnym obrazu był wykolejony z szyn i ustawiony w poprzek ulicy tramwaj, którego funkcja również uległa diametralnemu odwróceniu - zamiast współtworzyć sprawną sieć komunikacyjną, stawał się jej zakłóceniem.

Ikona techniki przemieniła się w narzędzie oporu. Taki obrót sprawy był zaskakujący o tyle, że w futurystycznych tekstach dochodziły do głosu zazwyczaj tematy inne: pochwała „życia niebezpiecznego”, intensywnych doznań, rekordowych osiągnięć, coraz doskonalszych maszyn, wreszcie znoszącej wszystkie ograniczenia oraz rozwijanej ad infinitum prędkości (Romani 1986). Skąd zatem w tym uniwersum barykada? Była ona wyraźnym sygnałem, że nowoczesny projekt upodmiotowienia mas powodował wstrząsy tektoniczne, które zapowiadały przemodelowanie ram życia zbiorowego. Jednak ich pierwszy (a często i jedyny) 
rezultat stanowiły protesty i zamieszki, podczas których zbiorowość przeistaczała się nie tylko w czarną (Sloterdijk 2003, 7-12), ale i czerwoną masę. W tym drugim przypadku zrewoltowany motłoch zamieniał się w proletariat, apokaliptyczne wizje rozwiewały się, a ich miejsce zajmowały napięcia oraz konflikty opisywane w kategoriach klasowych.

Tak było w utworze Jankowskiego. Pierwsze wersy - „niebieskie oczy proletariatu.../ tak jak niebieski jest nad Polską świt” (Yankowski 1920, 2) - wprowadzały w wyraźny sposób perspektywę klasową, uwikłaną w szerszy krąg metaforycznych skojarzeń, którym patronowała analogia między nastaniem pokoju a rosnącym znaczeniem proletariatu. W wierszu najciekawszy bodaj był fakt, że jego „oczy” były niebieskie, ale on sam nie był „czerwony”, Jankowski sięgnął bowiem po dobrze umocowany w tradycji literackiej obraz „czarnej masy”: „Fabryki kominy czarne jak sztandary,/ czarne niby lotny dzielnic ludu proch”. Na pierwszy plan została zatem wysunięta eksplozywność „ludu”, co płynęło z faktu, że podmiot skłonny był raczej opiewać bohaterski czyn (utwór miał podtytuł „rapsod”) niż przyświecające mu polityczne idee. Chociaż sam konflikt został przeniesiony na poziom symboliczny i przedstawiony jako walka dwóch żywiołów: wody i ognia, to - jak wskazuje sam tytuł utworu - Jankowski z rozmysłem nawiązał do rewolucyjnej ikonografii, która przenikała do polskiego futuryzmu zza wschodniej granicy. Głównie za sprawą płynących stamtąd inspiracji w tekstach polskich futurystów pojawiały się rewolucyjne akcesoria i tematy: czerwone sztandary, prześladowania robotników, wiece, pochody, demonstracje oraz przepowiednie nieuchronnie zbliżającego się końca starego porządku. Integralną częścią tego imaginarium była również barykada (Hazan 2015), która w wierszu Jankowskiego ujawniała istnienie żywiołu równie silnego, co wychwalana przez futurystów technika, a jednocześnie o wiele bardziej nieprzewidywalnego.

Tram w popszek ulicy opiewał jego moc. W wierszu Jankowskiego obraz wywróconego pojazdu nabierał dodatkowych sensów, bo umieszczony został wewnątrz matrycy dyskursu futurystycznego, który opierał się przecież na apoteozie techniki. Tymczasem tytułowy tramwaj nie wpisywał się w taki krąg skojarzeń, zwłaszcza że był - co warto podkreślić - przewrócony, a nie wykolejony z powodu zbyt szybkiej jazdy. W tym drugim wariancie można byłoby go uznać za jeden z eksponatów „muzeum wypadków” opisywanego przez Paula Virilia (2007, 35-44), względnie przypisać ówczesnym krytykom techniki, dla których wyrzucony z szyn pociąg mógł stanowić wizualną metaforę krachu nowoczesności. W wierszu Jankowskiego katastrofa nie była efektem przypadku czy błędu ludzkiego, ale - przeciwnie - stanowiła rezultat celowej dzia- 
łalności robotników. Stworzona przez nich barykada powodowała zmianę w codziennej cyrkulacji sił składających się na funkcjonowanie miasta, tamowała ich przepływ, a jednocześnie - w innym planie - odsłaniała istnienie utajonej gospodarki energetycznej będącej ciemnym rewersem nowoczesności. Tworzyły ją negatywne afekty, gromadzone wraz z postępującą modernizacją oraz wybuchające w nieprzewidzianych rewoltach, kiedy to zbuntowana masa ujawniała hipnotyzującą potęgę. W tych eksplozywnych momentach opiewana przez futurystów energia mas wchodziła na kolizyjny kurs z modernizacją, bo jej moc - inaczej niż w przypadku maszyn - nie poddawała się kontroli i wyładowywała w aktach spontanicznej destrukcji.

\section{„Abecadło rzezi” i karnawał}

Do futurystycznej poezji przenikały wątki karnawałowe, których geneza była o tyle złożona, że w twórczości reprezentantów tego nurtu zachowały się również powidoki wojny i rewolucji. Taki bagaż doświadczeń znacząco komplikował jej obraz, wplątywał w tkankę poszczególnych utworów elementy genetycznie związane z innymi odłamami awangardy (ekspresjonizm, dadaizm) (Bojtár 1972). Kiedy futurystyczne uniwersum nawiedzały widma przeszłości (zresztą nie tylko najnowszej), wszystkie stereotypowe cechy tego nurtu ulegały zmąceniu, a egzorcyzmowana z manifestów historia przenikała do tekstów. Wydaje się, że to właśnie za jej sprawą poezję polskich futurystów cechowały mroczne, paroksystyczne akcenty, które tak trudno uzgodnić z progresywizmem cywilizacyjnym.

Rezultatem tego kryzysu był wahadłowy ruch od cywilizacji do okrucieństwa. Wyznaczył on ramy koncepcyjne poematu Anatola Sterna Europa, w którym kontynent przedstawiony został jako przestrzeń zdestabilizowana, rozrywana przez napięcia i konflikty. A także podminowana przez negatywne afekty niepoddające się racjonalizacji, takie jak świeże wspomnienia wojenne, niemożliwe do przełożenia na uporządkowany i logiczny ciąg obrazów: „Film wojny światowej/ realizatorzy/ operatorzy/ oślepieni/ napisy wszystkie wytarte/ niepodobna zrozumieć/ ryczącej gestykulacji/ miliarda rąk/ przeszarżowanej gry aktorskich oczu/ film szaleństwa” (Stern 1985, 200-206). Odwołanie do stylistyki kina niemego, które dla awangardzistów było ważną inspiracją w tworzeniu nowego języka artystycznego, w tym przypadku podporządkowane zostało zasadzie kontrastu, opartego na zestawieniu traumatycznych doświadczeń wojennych z milczeniem, jakie towarzyszyło przedstawie- 
niu tłumów biorących udział w wojennym koszmarze. Wizualna retoryka pacyfistyczna, patronująca wielu ówczesnym reprezentacjom wojny (Sontag 2010), wypadała z antymilitarnej ramy dyskursywnej, „widok cudzego cierpienia” powodował jedynie głęboki szok, którego nie dało przełożyć się na logiczne kategorie.

„Wytarte napisy” odsłaniały słabość języka, bezradnego wobec wydarzeń, których nie sposób było zamknąć w tekstowo-dyskursywny porządek, w zamian pojawiała się oparta na automatycznym porządku enumeracja: „ABC/ abecadło rzezi/ brudu wesz pożarów/ i miłosierdzia”. Dotyczyła ona jednak nie tylko lat Wielkiej Wojny, lecz również - a może nawet przede wszystkim - lat powojennych, które jawiły się jako czas wszechogarniającego chaosu, podobnie jak to miało miejsce w wielu ciążących w stronę dadaizmu tekstach, gdzie początek lat dwudziestych przypominał bardziej „wesołe ruiny” niż stabilny początek nowej epoki (Sheppard 2000, 363; Delaperrière 2004, 134-136). Antycywilizacyjny impuls, który patronował temu kierunkowi, wywodził się z przekonania o głębokim kryzysie, jaki trawił kulturę europejską, oraz wyładowywał się w tekstach podważających kluczowe narracje nowoczesności. Zamiast opowieści o doskonaleniu się człowieka podsuwał perspektywę zupełnie inną, opartą na przeciwstawieniu „wysokich morderstw cywilizacji” oraz „ekstazy zmysłowości” (Stern 1985, 204). Pierwsze układały się w „abecadło rzezi”, druga z kolei otwierała furtkę pozwalającą na ucieczkę z okrutnego świata kultury i prowadziła do apoteozy karnawałowej z ducha cielesności.

Wątki te zbiegały się w wierszu Rewolucja ćała (Stern 1985, 145-149). W prowokacyjnym tytule, który splatał w jeden ciąg skojarzenia polityczne i obyczajowe, dochodził do głosu impuls emancypacyjny, jaki spełniał się w przekorny wobec nowoczesności sposób, ponieważ patronowało mu hasło porzucenia konwenansów i ról społecznych. Wyzwolenie miało być gestem totalnym, obejmującym całą zbiorowość, a jednocześnie odbyć się poza sferą kulturowo-cywilizacyjną, bo zwrot ku wypieranej przez dominujące dyskursy cielesności dokonywał się - paradoksalnie - przy akompaniamencie metaforyki sakralnej. Podmiot zwracał się do „tłumu szalonyh adamuw i pięknyh nagih ew”, nazywał go „milionem cudownyh spoconyh zbawićeluw!”, wreszcie - opiewał rzeczywistość, gdzie każdy mógł „dosięgnąć ńeba nogami”.

Poemat był apoteozą „wszechświatowego karnawału”. Dadaistyczna z ducha negacja kultury zawieszała nowoczesność wraz z jej represyjnymi zasadami, a jednocześnie powoływała na jej miejsce rzeczywistość, która pod pewnymi względami przypominała mityczną krainę Kukanii, jaką kilka stuleci wcześniej stworzyła kultura plebejska. Regresywność 
poematu Sterna miała przy tym charakter przewrotny, mieszała konteksty kulturowe i adresy polemiczne, a jednocześnie forsowała myśl, że apoteoza nieskrępowanego niczym szczęścia rozpoczyna się tam, gdzie ludowe marzenia biorą górę nad kulturowymi regułami: „Nieh żyje żywy człowiek!/ wszyscy wszyscy prędzej na ulice/ i na popszewracanych tramwajach/ jak na czerwonyh dzwońącyh stołach/ rozstawće woły w kolorowyh miash/ i ogroduw bukiety dookoła”. Przewrócone tramwaje nie służyły tutaj - jak to miało miejsce w wierszu Jankowskiego - za barykady, które miały dać schronienie zrewoltowanym masom, przeistaczały się natomiast w przygotowane do uczty stoły, zaś miejsce podszytego katastrofizmem koszmaru zajmował sielankowy sen o szczęściu i sytości.

Poeta świadomie przeinaczył dyskurs konser-

watywny, ponieważ opisał „duszę tłumu” przy

użyciu podobnych określeń, jakimi posługiwali się zawzięci krytycy „najeźdźcy wertykalnego” (Ortega y Gasset, 2016), a jednocześnie wplątał ten słownik retoryczny w zupełnie inny horyzont

znaczeń; zburzenie kościoła stawało się założycielskim mitem nowej wspólnoty, wrzask

mas urastał do rangi nowej pieśni braterstwa.

\section{Mściciel, mistyk, moralista}

Rzeź i karnawał nie wykluczały się wzajemnie. W futurystycznej poezji reprezentacje mas często opierały się łączeniu tych dwóch elementów, zaś ich spoiwem była retoryka rewolucyjna, jak na przykład w $Z$ dobyciu Paryża Sterna: „Tak! Z gruzów Paryża, Warszawy, Londynu, Tuluzy,/ wraz z krwią jasną w przestworza tryska słodki blask!/ Nieśmiertelnym kościołem są kościoła gruzy -/ I śpiewem braterstwa jest błędny tłumu wrzask" (Stern 1985, 222). Poeta świadomie przeinaczył dyskurs konserwatywny, ponieważ opisał „duszę tłumu” przy użyciu podobnych określeń, jakimi posługiwali się zawzięci krytycy „najeźdźcy wertykalnego" (Ortega y Gasset, 2016), a jednocześnie wplątał ten słownik retoryczny w zupełnie inny horyzont znaczeń; zburzenie kościoła stawało się założycielskim mitem nowej wspólnoty, wrzask mas urastał do rangi nowej pieśni braterstwa. W ten sposób dwa ciagi znaczeniowe - destrukcji i sztuki - splecione zostały na nowych zasadach, podobnie zresztą jak w Europie, gdzie była mowa o „nadrealistycznym kamarinskim równości klasowej/ pod którym się zapada posadzka Europy”.

Związek między rewolucją, pieśnią i tańcem był kluczową cechą Stowa o Jakubie Szeli (1926) Jasieńskiego. Najwyraźniej zaznaczał się we fragmentach opisujących bunt chłopów, gdzie wyczuwalne były echa karmanioli, rewolucyjnego tańca, jaki ze sporą dozą zjadliwości przedstawił niespełna sto lat wcześniej Zygmunt Krasiński w Nie-Boskiej Komedii. Zbuntowani chłopi intonowali w poemacie Jasieńskiego krwawą pieśń, w której nawoływali do bezwzględnego rozprawienia się ze szlachtą: „Hulaj! wychylaj głowy zza wnęk!/ Byli - ubyli, jechał ich sęk! Hola na pola orki się uczyć,/ orać karbowym, rządcą nawłóczyć!” (Jasieński 2008, 185). Ich rewolta została ukazana jako czas zapustów, co wyraźnie zresztą 
uwypukliła klamrowa kompozycja; utwór rozpoczynał się weselną zabawą, kończył - nadejściem postu. Między nimi umieszczony został „taniec opętaniec”, czyli rabacja: „Tańcowali z chłopem pan/ milczkiem-boczkiem koło ścian/ Tańczył rządca, tańczył dziedzic,/ żaden nie chciał w miejscu siedziećl (...) Tańcowali raz po raz./ Chłopska kosa pański pas./ Od ogródka do ogródka/ ciekła rowem krew jak wódka” (Jasieński 2008, 183). Rzeź galicyjska - podobnie jak karnawał - była czasem zawieszenia dotychczasowych reguł, dlatego Jasieński przefiltrował ją przez poetykę groteski (Rawiński 1971), która przerzucała prowokacyjny pomost pomiędzy rzezią a zapustową zabawą. Perspektywa taka doprowadziła do wyraźnego przetasowania w języku artystycznym; autor zrezygnował z ortografii fonetycznej i zastąpił ją folklorem, co o wiele lepiej pasowało do koncepcji wyłożonej w przedmowie do poematu.

Jasieński nawoływał do porzucenia „z wersalska strzyżonych alej historii oficjalnej”. Gest wyjścia poza utarte szlaki miał w tym wypadku przede wszystkim wymiar klasowy, co przekładało się wyraźnie na estetyczną reprezentację zrewoltowanej grupy, która opisywana była w sposób odbiegający od topiki „czarnej masy”; chłopi mieli nie tylko swojego przywódcę, ale również długi rachunek krzywd oraz argumenty społeczno-ekonomiczne. Futurystyczny eksperyment ustępował zatem miejsca sprawom, które jawiły się jako o wiele bardziej doniosłe, zaś artystyczna subwersja została przeniesiona z estetyki w wymiar historyczny, czemu patronowała próba zakwestionowania konserwatywnej narracji o chłopskim buncie. Inspiracją do podjęcia takiej próby stała się książka Ludwika Dębickiego $Z$ dawnych wspomnień (1846-1848) - zreferowano w niej opinie naocznych świadków krwawych wydarzeń, które Jasieński przytoczył in extenso:

Nie był to ich zdaniem pospolity zbrodniarz, nie działał jak inni w stanie opiłym, z wściekłością dzikiego zwierza. Trzeźwy i spokojny, miał na ustach słowa Pisma Św.; gdy mordował i pastwił się nad swoimi ofiarami, wtedy jeszcze występował jako moralista i mściciel. Zdawał się być mistykiem i sekciarzem w siermiędze (Dębicki 1903, 57).

Pisarz wychwycił w tym portrecie niekonsekwentne rysy. Z jednej strony Szela został opisany jako mściciel, który dopuszczał się najokrutniejszych czynów, z drugiej jednak jego postępków nie dało się zracjonalizować, sięgając po charakterystyczne dla konserwatywnego dyskursu o masach argumenty szaleństwa („stan opiły”) oraz animalizacji („dziki zwierz”). Jednocześnie Jasieński obrócił owe niekonsekwencje na korzyść „chłopskiego króla”, przedstawiając jego czyny jako rezultat buntu prze- 
ciwko niesprawiedliwemu porządkowi świata w wymiarze tak doczesnym, jak i metafizycznym. Szela nie wystąpił jedynie przeciwko bezdusznej maszynie władzy administracyjnej, jego motywacje wykraczały wyraźnie poza „tu i teraz”, co podkreślone zostało w scenie spotkania z Chrystusem, który spieszył na pomoc mordowanej szlachcie. Sytuacja rozmowy z Bogiem została przeniesiona poza horyzont mistyczny, sprawy wiary okazały się o wiele mniej istotne niż doczesne cierpienie człowieka, dlatego to właśnie Szela wyszedł z tego retorycznego pojedynku zwycięsko, odsyłając Jezusa do nieba.

Jasieński z wyrachowaniem stworzył legendę postaci, która rozmawiała nie tylko z Bogiem, ale i z naturą, co było cechą charakteru często przypisywaną ludowym świętym w plebejskim imaginarium. Szela przed podjęciem ważnych decyzji naradzał się z drzewami, a moment jego aresztowania przez żandarmów urastał do rangi kosmicznego występku przeciwko odwiecznym prawom, których naruszenie spotkało się z natychmiastową reakcją przyrody: "Jak go prowadzili/ tamtą kładką giętą,/ wyszły ryby na przerębel/ łapać ludzi wędką.// W całej rzece wielki/ narobiły ruch tem/ jak po lodzie jak te kundle/ biegły za nim truchtem”. I dalej: „Jak go wiedli bagnem,/ tym, co śmierci dar ma,/ wyszli wilcy, zjedli w lesie/ jednego żandarma” (Jasieński 2008, 190). Poetyka absurdu, wyraźnie korespondująca z obrazem karnawałowego „świata na opak” wpleciona została w tryby strategii mitotwórczej, podporządkowanej stworzeniu portretu ludowego przywódcy, wygnanego na marginesy dziejów przez siły, którym odważył się rzucić wyzwanie.

Stowo o Jakubie Szeli zostało pomyślane jako kontrnarracja. Jasieński pisał z przekąsem na temat „historii oficjalnej”, zarzucał jej wszystkie możliwe błędy, począwszy od ignorowania i przemilczania faktów, poprzez manipulację, a skończywszy na fałszywej interpretacji. Postulowana przez niego korekta nie dotyczyła jedynie spraw minionych, bo kiedy pisał, że przywódca rabacji został potępiony ze względu na dominującą w minionym stuleciu „koncepcję narodową” i za jej sprawą oskarżony o współpracę z zaborcą, to jego celem nie były wyłącznie porachunki historyczne. Polemika ta miała aktualny adres, jej ostrze skierowane zostało przeciwko dyskursowi państwotwórczemu, który tworzył współczesny panteon na gruncie zeszłowiecznych wartości. Dlatego też pisał, że „gdyby nawet Szela historyczny nie istniał, to w interesie o cały świat świadomości klasowej wzbogaconej kultury polskiej, należałoby go wymyślić”. I zaraz prowokacyjnie dodawał: „Gdyby Szela istniejący nie był bohaterem, to i wówczas, w imię męczeńskiej epopei krzywdy chłopskiej, należałoby go dźwignąć na wyżyny heroizmu” (Jasieński 2008, 144). 
Był to heroizm, który realizował się nie tyle jako zaprzeczenie kodeksu patriotycznego, ile raczej sytuował się całkowicie poza jego obrębem, Jasieńskiego nie interesował bowiem stosunek tytułowego bohatera do Polski, ale do władzy austriackiej, która zesłała Szelę na Bukowinę, ponieważ jego „ogromny autorytet (...), zwrócony raz przeciwko władzy rządowej, stawał się dla niej na przyszłość elementem niebezpiecznym, precedensem do dalszych buntów i nieposłuszeństw" (Jasieński 2008, 144). W tak sformułowanej diagnozie rezonował nie tyle ton historyka, ile raczej zaangażowanego w ówczesne spory artysty, który mierzył heroizm postaci skalą braku pokory wobec władzy. Jasieńskiego interesował nie tyle Szela-postać historyczna, ile Szela-działacz rewolucyjny, bez wahania rzucający wyzwania silniejszym i niecofający się przed okrucieństwem, zarazem charyzmatyczny polityk, umiejętnie wykorzystujący gniew upokorzonych chłopów. Mówiąc najkrócej: nowoczesny trybun ludowy, który posiadł umiejętność oddziaływania na emocje i wyobraźnię mas.

Poezja futurystyczna towarzyszyła wejściu kultury polskiej do „odczarowanego” świata, w którym coraz głośniejszym echem rozchodził się postulat upodmiotowienia mas. Formacja awangardowa od samego niemal początku wspierała ten proces, choć z reguły nie potrafiła przełamać pefrormatywnej sprzeczności między sferą deklaracji o rozpuszczeniu sztuki w życiu społecznym a dość wymagającą dla odbiorcy formą artystyczną. Wprawdzie nowatorskie dyskursy estetyczne generowały różne rozwiązania tej sprzeczności, lecz nie wyszły one poza sferę projektów, ostatecznie żadne z nich nie zdołało jej uchylić, a tam, gdzie to się (zresztą tylko pozornie) udawało, sztuka osuwała się w agitatorstwo, totalitarną inżynierię dusz, wreszcie - jak było w zSRR - w biurokratyczną nudę (Groys 2008, 148). Fiaskiem zakończyły się także próby podejmowane przez rodzimych futurystów, ale z dzisiejszej perspektywy interesujący wydaje się nie tyle (czy: nie tylko) ostateczny bilans ich działań, ile raczej literackie konsekwencje prób porzucenia idei autonomii sztuki na rzecz społecznego i politycznego zaangażowania. Pod wpływem emancypacyjnych haseł ich poezja nabierała nie tylko innego charakteru, lecz również odmiennych barw.

W wierszach futurystów masa bywała zazwyczaj „czarna” lub „czerwona”. Pierwszy sposób reprezentacji odwoływał się do konwencji wczesnego modernizmu, który chętnie operował wysnutymi z dyskursu konserwatywnego kliszami, przedstawiającymi każdą samorzutną aktywność tłumu jako złowrogą i destrukcyjną. Drugi nawiązywał do ikonografii lewicowej i niósł ze sobą odwołania do podziałów klasowych oraz
Jasieńskiego interesował nie tyle Szela-

-postać historyczna, co Szela-działacz rewolucyjny, nie wahający rzucić się wyzwania silniejszym i nie cofający się przed okrucieństwem, a zarazem charyzmatyczny polityk, umiejętnie wykorzystujący gniew upokorzonych chłopów. Mówiąc najkrócej: nowoczesny trybun ludowy, który podsiał umiejętność oddziaływania na emocje i wyobraźnię mas. 
idei rewolucji. W obu przypadkach barwy przestawały być metaforycznymi ornamentami, odsyłały natomiast do odmiennych porządków wyobrażeniowych, na podstawie których futuryści konceptualizowali dynamicznie zmieniającą się współczesność. W zależności od perspektywy masa miała nie tylko inny kolor, ale także stan skupienia i tożsamość, za sprawą dominacji czerwieni (której z upływem czasu było coraz więcej) z tekstów znikał bezimienny, targany chaotycznymi porywami motłoch, a jego miejsce poczynały zajmować grupy proletariackie, robotnicze bojówki oraz chłopskie gromady. Wraz z tą zmianą z tekstów wyparowywała apokaliptyczna tonacja, co miało znaczny wpływ na sposób, w jaki przedstawiano rewolucję społeczną - zaczynała ona być traktowana nie tylko jako wybuch pierwotnych instynktów, lecz również jako uzasadniony bunt przeciwko generowanym przez kapitalizm nierównościom.

\section{Wykaz literatury}

Bereś, Stanisław. 1979. „Futurystyczna baśń o cywilizacji”. Miesięcznik Literacki 2.

Bojtár, Endre. 1972. „Awangarda wschodnioeuropejska jako kierunek literacki”. Tłum. J. Walicka. Miesięcznik Literacki 11-12.

Delaperrière, Maria. 2004. Polskie awangardy a poezja europejska. Studium wyobraźni poetyckiej. Tłum. Adam Dziadek. Katowice: Wydawnictwo Uniwersytetu Śląskiego.

Dębicki, Ludwik. 1903. Z dawnych wspomnień (1846-1848). Kraków: Spółka Wydawnicza Polska.

Eksteins, Modris. 1996. Święto wiosny: wielka wojna i narodziny nowego wieku. Tłum. Krystyna Rabińska. Warszawa: Państwowy Instytut Wydawniczy.

Groys, Boris. 2008. Art Power. Massachusetts: MIT Press.

Hazan, Eric. 2015. A History of the Barricade. Tłum. D. Fernbach. Verso: London.

Jasieński, Bruno. 2008. Poezje zebrane. Wstęp, komentarz i oprac. Beata Lentas. Gdańsk: słowo/obraz terytoria.

Le Bon, Gustaw. 1994. Psychologia tłumu. Tłum. Bolesław Kaprocki. Warszawa: Wydawnictwo Naukowe PwN.

Linde, Samuel. 1809. Stownik języka polskiego. т. 2, cz.1: M-o. Warszawa: nakładem autora.

Loth, Roman. 1965. „»Kultura Robotnicza« - „Nowa Kultura« 1922- 
1924. Szkic z dziejów prasy kulturalno-oświatowej KPRP”. Przegląd Humanistyczny 1.

Ortega y Gasset, José. 2016. Bunt mas. Tłum. Piotr Niklewicz. Zakrzewo: Replika.

Niedźwiedzki, Władysław, Adam Antoni Kryński i Jan Karłowicz (red.). 1902. Stownik jezyka polskiego. T. 2. H-W. Warszawa: Kasa im. Mianowskiego.

Peiper, Tadeusz. 1972. Tędy. Nowe Usta. Kraków: Wydawnictwo Literackie.

Przybyszewski, Stanisław. 1899. „Confiteor”. Życie 1.

Pułka, Leszek. 1993. Hołota, masa, ttum. Bohater zbiorowy w prozie polskiej 1890-1918. Wrocław: Wydawnictwo Uniwersytetu Wrocławskiego.

Rawiński, Marian. 1971. „Słowo o Jakubie Szeli Brunona Jasieńskiego wobec folkloru”. Pamiętnik Literacki 1.

Romani, Bruno. 1986. Le futurisme. Italie et France. W Les avant-gardes litteraires au XXe siècle. т. 1: Histoire. Red. Jean Weisgerber. Budapest: Akadémiai Kiadó.

Sajewska, Dorota. 2016. Nekroperformans. Kulturowa rekonstrukcja teatru wielkiej wojny. Warszawa: Instytut Teatralny imienia Zbigniewa Raszewskiego.

Sheppard, Richard. 2000. Modernism - Dada-Postmodernism. Evanston: Northwestern University Press.

Sloterdijk, Peter. 2004. Pogarda mas. Szkic o walkach kulturowych we współczesnym społeczeństwie. Tłum. Bogdan Baran. Warszawa: Czytelnik.

Sontag, Susan. 2010. Widok cudzego cierpienia. Tłum. Sławomir Magala. Kraków: Karakter.

Sorel, Georges. 2014. Rozważania o przemocy. Tłum. Marek J. Mosakowski. Warszawa: Wydawnictwo Krytyki Politycznej.

Stern, Anatol. 1985. Wiersze zebrane. т. 1. Oprac. Andrzej K. Waśkiewicz. Kraków: Wydawnictwo Literackie.

Tarde, Gabriel de. 1904. Opinia i tłum. Tłum. Kazimiera Skrzyńska. Warszawa: Gebethner i Wolff.

Virilio, Paul. 2007. Wypadek pierworodny. Tłum. Krystyna Szeżyńska-Maćkowiak. Warszawa: Sic!

Walicki, Andrzej. 2011. Prace wybrane. T. 3: Stanisław Brzozowski - drogi myśli. Kraków: Universitas.

Yankowski, Yeży. 1920. Tram wpopszek ulicy: skruty prozy i poemy. Warszawa: Futuryzm Polski. 
ALEKSANDER WÓJTOWICZ - historyk literatury, edytor, adiunkt w Zakładzie Literatury xx i xxI wieku Instytutu Filologii Polskiej uMCs. Zajmuje się dziejami europejskich ruchów awangardowych, współczesną sztuką eksperymentalną oraz edytorstwem literatury dwudziestego wieku. Autor książek Cogito i „sejsmograf podświadomości”. Proza Pierwszej Awangardy (Lublin, 2010) oraz Nowa Sztuka. Początki (i końce) (Kraków, 2017), współredaktor monografii, edycji krytycznych i popularnych, publikował m.in. w „Pamiętniku Literackim”, „Ruchu Literackim”, „Tekstach Drugich”, „Kwartalniku Filmowym”.

\section{Dane adresowe:}

Instytut Filologii Polskiej UMCS

pl.M. Curie-Skłodowskiej 4A, 20-031 Lublin

Tel. 815375190

email: aleksander.wojtowicz@poczta.umcs.lublin.pl

\section{Cytowanie:}

Wójtowicz, Aleksander. 2019. „Czarne i czerwone. Masy ludzkie w poezji polskiego futuryzmu". Praktyka Teoretyczna 3(33): 29-44.

DOI: $10.14746 /$ prt.2019.3.3

Author: Aleksander Wójtowicz

Title: Black and red: Human masses in the poetry of Polish futurism

Abstract: The article shows how the political engagement of Polish futurism influenced its poetic representations of crowds. Futurists showed masses as a reservoir of energy strong enough not only to destroy the old regime but also to create a framework for the new order. They described the masses by employing elements of different discourses - conservative, communist and military. These heterogenic representations were bound together by the apotheosis of the revolution against the normative order of modernity (and capitalism).

Keywords: futurism, avant-garde, mid-war period, revolution, barricade, Bruno Jasieński, Anatol Stern 